\title{
Effects of small-diameter silver nanoparticles on microbial load in cow milk
}

\author{
N. Yildiz and A. Pala ${ }^{1}$ \\ Department of Animal Science, Canakkale 18 Mart University, Canakkale, Turkey
}

\begin{abstract}
Controlling bacterial growth in fluid milk is of economic interest, and supplemental methods to stop or reduce bacterial growth before and during the cooling chain may be valuable. Silver is effective in controlling growth of single-celled organisms, but has no effect on tissue cells. Smaller diameter $(6-8 \mathrm{~nm})$ silver nanoparticles were produced, with purity over $99.99 \%$ (no chemical reaction used in the process), by using a terminated gas condensation principle. The first trial investigated effects of time, temperature, and accelerating voltages on total aerobic bacteria count in control milk and milk treated with silver nanoparticles. Metal braids were coated with silver nanoparticles using 3 accelerating voltages, 0,100 , and $200 \mathrm{~V}$, the results of which indicated that the braids coated using $100 \mathrm{~V}$ (AgNP100) were optimal. The AgNP100 particles were effective at all treatment temperatures and durations except for $10 \mathrm{~h}$, which indicated that the treated milk could be used after $10 \mathrm{~h}$ for other dairy products such as yogurt, which require microbial activity. The second experiment investigated the effects of silver nanoparticles on counts of yeasts and molds, coliform bacteria, Escherichia coli, and Staphylococcus aureus in cow milk by treating milk with AgNP100 braids at $22^{\circ} \mathrm{C}$ for $1 \mathrm{~h}$. Inductively coupled plasma mass spectrometry analyses indicated that the maximum amount of silver found in the AgNP100-treated milk was $6.1 \mu \mathrm{g} / \mathrm{L}$, which is below the safety limits. Counts in milk samples containing the nanoparticle-coated braids were lower for all yeasts and molds and bacteria investigated compared with the control milk samples, which were kept under the same conditions but without the braids. The differences were significant for coliforms, Escherichia coli, and Staphylococcus aureus but not for yeasts and molds, although ranking of the counts $(\mathrm{AgNP} 100<$ initial load $<$ control) were the same for all microorganisms. Small-diameter, silver nanoparticle-coated braids can stop or reduce bacterial growth in fluid milk. Silver
\end{abstract}

Received August 10, 2011.

Accepted October 30, 2011.

${ }^{1}$ Corresponding author: dr.akin.pala@gmail.com nanoparticles inhibited microbial growth and may be useful in complementing the cooling chain and the thermal processes. These results warrant more research on the sensory properties and long-term safety of the use of silver nanoparticles in dairy products.

Key words: nanotechnology, silver nanoparticle, cow milk, inductively coupled plasma mass spectrometry

\section{INTRODUCTION}

Milk is a product that needs to be kept cold until thermal processing, and milk that waits on the farm between milkings may not be kept cold at all times. Bacteria may grow before and during transport, even in the cooled tanks (psychrotrophic bacteria), and increases in the number of bacteria decreases milk quality. Toxic materials left by dead bacteria such as Staphylococcus aureus change milk's aroma, taste, and visual properties, and the toxic materials withstand pasteurization (Cenci-Goga et al., 2003). Dairy products such as cheese and yogurt are affected negatively by bacteria even after bacteria are killed by the thermal process. The best solution is to inhibit bacteria from growing in the first place. Silver nanoparticles (AgNP) can be used in conjunction with current processes to keep milk safer until it reaches the thermal processing step. These methods may be used before and during the cooling chain by coating automatic milking systems (Speroni et al., 2006) and items such as milk cans, bulk tanks, or milk pipes with these antibacterial particles.

Particles $<500 \mathrm{~nm}$ are called nanoparticles, and nanoparticles are measured in nanometers $(1 \mathrm{~nm}=$ $\left.10^{-9} \mathrm{~m}\right)$. An atom is $\geq 0.1 \mathrm{~nm}$, viruses are $\geq 10 \mathrm{~nm}$, bacteria are around $1,000 \mathrm{~nm}$, and a human hair is $100,000 \mathrm{~nm}$ in diameter. Baker et al. (2005) reported that the smaller the silver nanoparticles, the greater their antibacterial effects, largely due to the increased surface to volume ratio and crystal surface structure. Normally, commercially available AgNP used for antibacterial purposes are around $50 \mathrm{~nm}$ in diameter.

Even though silver is beneficial to use against bacteria, its use has been severely limited due to expense. With current nanotechnology, however, bacteria can be killed more effectively and cost efficiently using AgNP compared with pure silver, because silver is expensive. 


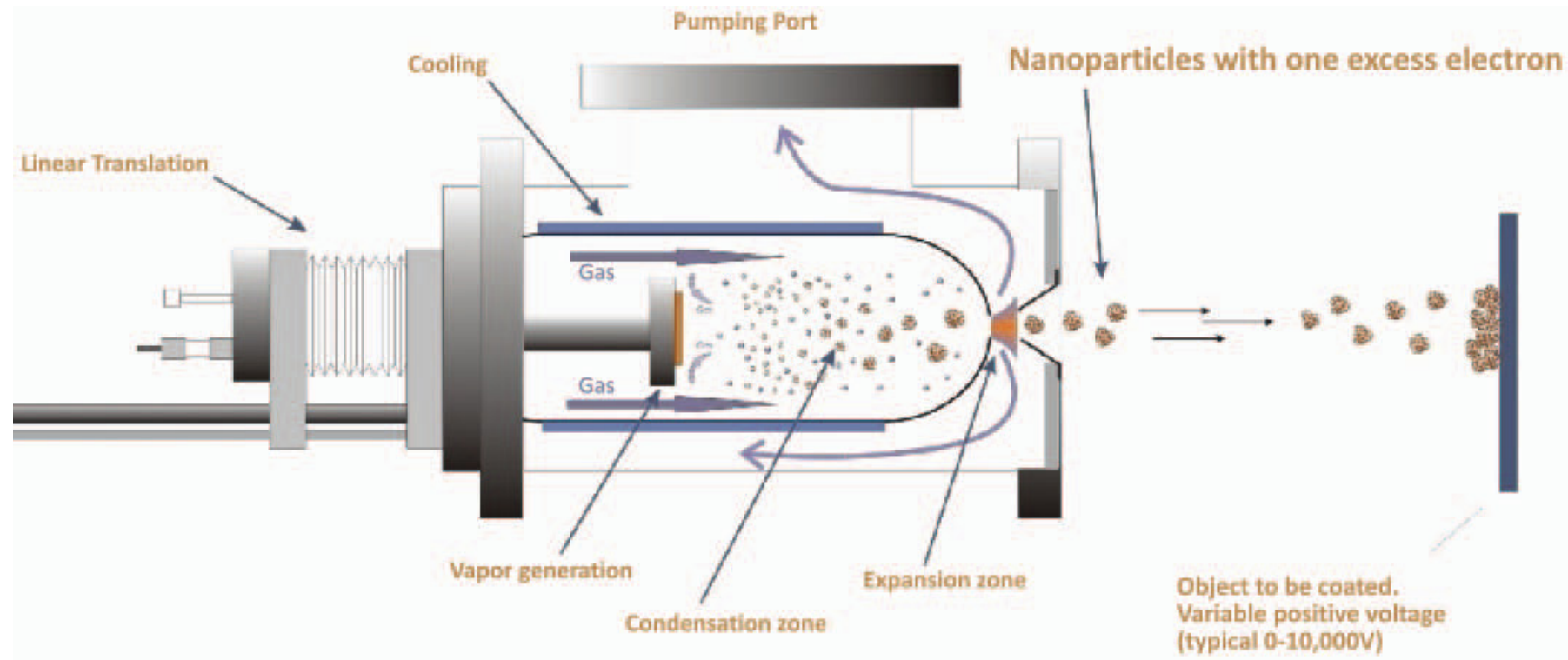

Figure 1. Mechanism for silver nanoparticle coating. Color version available in the online PDF.

Baker et al. (2005) reported that $1 \mathrm{~g}$ of AgNP could be used to coat 1,000 to $3,000 \mathrm{~m}^{2}$ of surface.

Bacteria are killed by AgNP mainly because silver has a high affinity for sulfur and the particles separate the disulfide bonds (-S-S-) of bacteria. This prevents the bacteria from controlling their own respiration process due to the suppressed respiratory enzymes ( $\mathrm{Li}$ et al., 2006). Silver particles also kill bacteria by helping produce reactive oxygen from the air or water. The reactive oxygen attached to the cell prevents its reproduction. This is similar to effects of the strong bases such as hydrogen peroxide (He et al., 2011).

Silver is effective on single-celled organisms that are damaged by oxygen and that respire chemically. The reference dose for oral silver exposure is $5 \mu \mathrm{g} / \mathrm{kg}$ of BW per day (Hill, 2009). Some studies have reported accumulation and harmful effects of AgNP (Tang and Xi, 2008; AshaRani et al., 2009; Kawata et al., 2009), whereas others reported no significant toxicological effects (Hyun et al., 2008) or no genetic toxicity-related reactions in repeated oral administration of AgNP (Kim et al., 2008). Park et al. (2010) reported harmful effects of AgNP in mice only in the high dose-treated group of $1,000 \mu \mathrm{g} / \mathrm{kg}$. Klueh et al. (2000) reported that silver ions or nanoparticles are toxic to bacteria and viruses but harmless to somatic cells, such as those found in humans and livestock. Lansdown et al. (1997) reported that silver did not have a toxic effect on rats, and that wounds treated with silver healed significantly faster compared with the control group and the wounds were bacteria free. Park et al. (2011) orally administered 7.9$\mathrm{nm}$ AgNP to mice, found the particles in the feces, and confirmed that absorption through the gastrointestinal tract was poor. Pedahzur et al. (1997) reported that silver has been used for sterilization in drinking water systems. However, because conflicting results are found in the literature, long-term safety studies evaluating the molecular mechanisms should be carried out if AgNP are found to be useful in the dairy industry.

Voccia et al. (2006) reported that surfaces coated with silver acetate were bacteria free. Graham (2005) noted that many studies reported that silver-based products decreased the microbial load on wounds, and the general conclusions of these studies were that silver is effective in killing harmful bacteria and its effectiveness depends on the form of the silver. In the medical field, clinical studies and studies done with animals indicate that products placed within the body had infection-preventive effects if coated with silver (Darouiche, 1999; Bertrand et al., 2000; Brutel de la Riviere et al., 2000). Panacek et al. (2006) produced dimensionally controlled AgNP and reported that these were highly antimicrobial.

Objectives of this study were to investigate the antimicrobial effects of small diameter $(6-8 \mathrm{~nm}) \mathrm{AgNP}$ in cow milk by studying the effects of accelerating voltage, time, and temperature on total aerobic count (TAC), and by exploring the particles effects on counts of yeasts and molds, coliform bacteria, Escherichia coli, and Staphylococcus aureus counts. The nano silver 
technology can be used in conjunction with the current technologies and can be useful to small farmers, small and medium businesses, and large dairy companies.

\section{MATERIALS AND METHODS}

Terminated gas condensation was used as the primary method for producing nanoparticles in this study (Figure 1). In this mechanism, particles form from vapor under high pressure (Pérez-Tijerina et al., 2008), enabling the system to produce small particles $(0.8 \mathrm{~nm})$ with narrow distribution and to produce pure materials. The tool used is a vacuum chamber of 500 $\times 400 \times 400 \mathrm{~mm}$. The system has 3 principal parts: the sample chamber, the nanoparticle chamber, and a rotating cage cylinder to hold items for coating. The instrument is evacuated by turbo pump and the operating pressure is around $0.001 \mathrm{~Pa}$. The system allows manipulation and measurement of nanoparticle size. The rotating cage allows any surface within reason to be coated with AgNP. The cage is electrically isolated to allow the electrical charge of items to be changed to allow acceleration of the nanoparticles. A process called physical vapor deposition is used. The vapor is generated using a technique called magnetron sputtering. A disk of silver is biased to a negative voltage, generating plasma above it. Argon ions are then attracted to the silver target at high energy; they collide and silver is vaporized, and this vapor is used to generate AgNP.

Microbiology and inductively coupled plasma mass spectrometry (ICP-MS) analyses were carried out in cow milk. The microbiology trial (Figure 2) investigated the effects of accelerating voltage, time, and temperature on TAC. Analyses used 3 different metal braids coated with AgNP using 0, 100, and $200 \mathrm{~V}$ of electricity, which was shown in pilot runs to be a logical range of voltages. The voltages used in coating the wires affect the kinetic energy and thus how much AgNP stick to the metal braids. Milk samples were incubated with AgNP wires coated using 0 (AgNP0), 100 (AgNP100), and 200 (AgNP200) V. These braids were incubated in milk for various predetermined times $(1 \mathrm{~s}, 30 \mathrm{~s}, 10 \mathrm{~min}$, $1 \mathrm{~h}$, and $10 \mathrm{~h}$ ) at 3 temperatures; thus, experiment 1 included 5 times $\times 3$ temperatures $\times 3$ wire types (voltages). Pilot trials indicated that several minutes should be enough to make a difference in bacterial load.

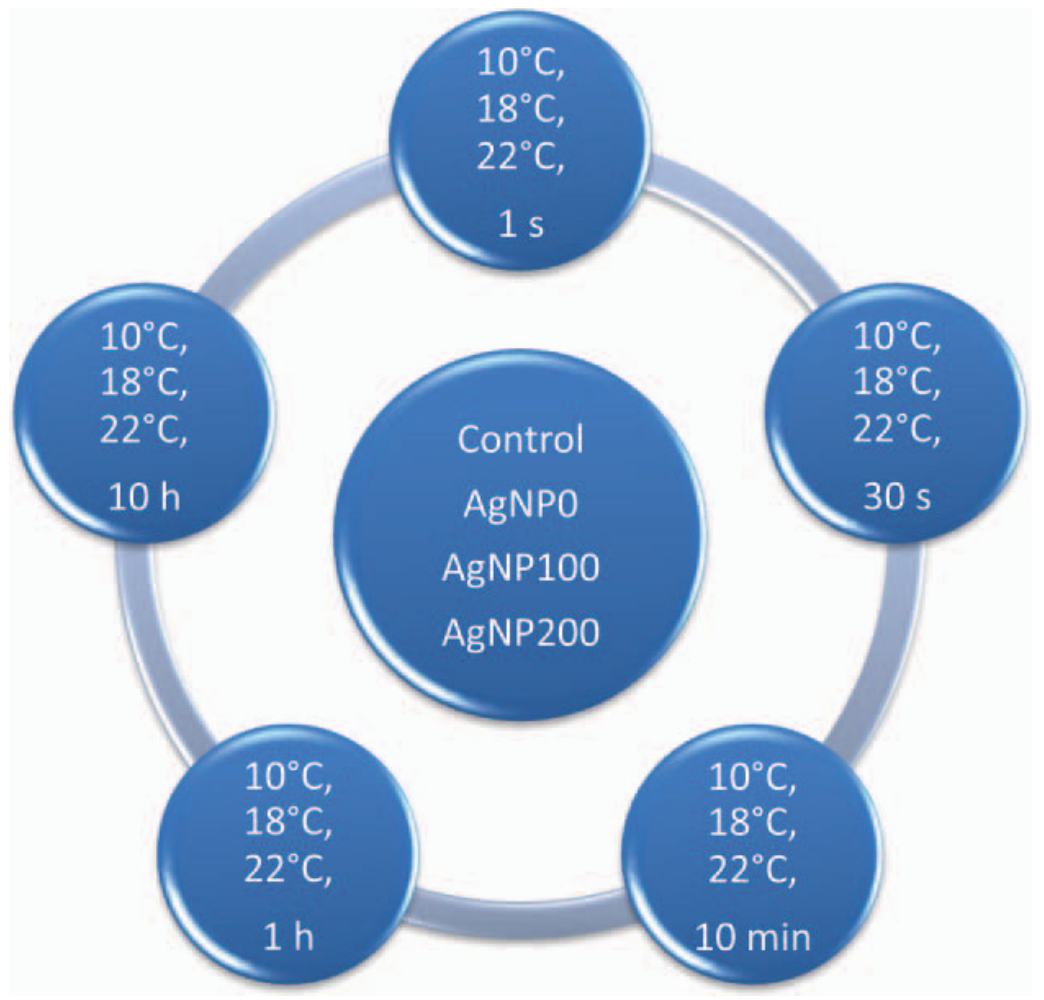

Figure 2. The first trial investigating effects of temperature, time, and accelerating voltage. Control = milk sample with no AgNP wire; AgNP0, AgNP100, and AgNP200 = milk samples incubated with AgNP wires coated using 0, 100, and $200 \mathrm{~V}$. Color version available in the online PDF. 
Table 1. Total aerobic count (TAC; $\mathrm{LSM} \pm \mathrm{SE}$ ) for silver nanoparticle $(\mathrm{AgNP})$ wires created using different accelerating voltages $(0,100$, and $200 \mathrm{~V})$

\begin{tabular}{lc}
\hline $\begin{array}{l}\text { Milk } \\
\text { sample }^{1}\end{array}$ & $\begin{array}{c}\text { TAC } \\
(\log \mathrm{cfu} / \mathrm{mL})\end{array}$ \\
\hline Control & $7.08^{\mathrm{A}} \pm 0.008$ \\
AgNP0 & $7.06^{\mathrm{B}} \pm 0.008$ \\
AgNP100 & $6.89^{\mathrm{D}} \pm 0.008$ \\
AgNP200 & $6.95^{\mathrm{C}} \pm 0.008$ \\
\hline
\end{tabular}

A-D Values with different superscripts differ $(P<0.05)$.

${ }^{1}$ Control $=$ milk sample with no AgNP wire; AgNP0, AgNP100, and AgNP200 = milk samples incubated with AgNP wires coated using 0, 100 , and $200 \mathrm{~V}$.

However, keeping milk for $10 \mathrm{~h}$ at these temperatures checks whether the particles continue to work as efficient inhibitors of bacterial growth. The temperatures were $10^{\circ} \mathrm{C}, 18^{\circ} \mathrm{C}$, and $22^{\circ} \mathrm{C}$ and were maintained using a water bath. This trial determined the efficiency of the effect of particles on TAC under different accelerating voltages, times, and temperatures.

In the second trial (Figure 3), microbiological analyses were run on fresh milk, pasteurized milk, treated milk (containing AgNP100 braids), and control samples. The samples had 3 replications and each replication was run in duplicate. The raw milk was analyzed for initial microbial load and then divided into samples for the treatment, pasteurization, and raw milk (control) samples. The AgNP-coated braids were kept in the treatment milk samples for $1 \mathrm{~h}$ at $22^{\circ} \mathrm{C}$. The control samples were kept at the same conditions without the braids. The milk samples to be pasteurized were also kept at $22^{\circ} \mathrm{C}$ for $1 \mathrm{~h}$. For pasteurization, a thermostatic water bath was used and the milk samples were kept at $65^{\circ} \mathrm{C}$ for $30 \mathrm{~min}$. The samples were analyzed for counts of coliform bacteria, E. coli, yeasts and molds, and Staph. aureus.

Milk samples were diluted using $0.1 \%$ sterile peptone water $\left(10^{-1}\right.$ to $\left.10^{-6}\right)$. Total aerobic mesophilic bacteria count was done using plate count agar after 24 to $48 \mathrm{~h}$ of incubation at $30^{\circ} \mathrm{C}$ (Dogan and Tukel, 2000). Yeasts and molds were counted using yeast extract glucose chloramphenicol medium after 3 to $4 \mathrm{~d}$ of incubation
Table 2. Total aerobic count (TAC; LSM \pm SE) for different temperatures

\begin{tabular}{lc}
\hline Temperature $\left({ }^{\circ} \mathrm{C}\right)$ & $\begin{array}{c}\text { TAC } \\
(\log \mathrm{cfu} / \mathrm{mL})\end{array}$ \\
\hline 10 & $6.86^{\mathrm{C}} \pm 0.007$ \\
18 & $7.09^{\mathrm{A}} \pm 0.007$ \\
22 & $7.04^{\mathrm{B}} \pm 0.007$ \\
\hline $\mathrm{A}^{\mathrm{C}}$ Values with different superscripts differ $(P<0.05)$.
\end{tabular}

${ }^{\mathrm{A}-\mathrm{C}}$ Values with different superscripts differ $(P<0.05)$.

at $28^{\circ} \mathrm{C}$ (Unluturk and Turantas, 1996); coliforms and $E$. coli were counted using violet red bile lactose methylumbelliferyl-b-D-glucuronide (MUG) agar after 18 to $24 \mathrm{~h}$ of incubation at $30^{\circ} \mathrm{C}$ (Cakir, 2000); and Staphylococcus aureus was counted using Baird-Parker agar (Tukel and Dogan, 2000). Parallel Petri dishes were counted, averaged, and multiplied by the dilution factor. One hundred-milliliter milk samples were used for the trials. The study was carried out under aseptic conditions to prevent any contamination. Control and treatment samples were kept under the same conditions, were from the same animals, and all other factors were the same.

The ICP-MS analyses were carried out to investigate the amount of silver left in the milk samples. For calibration, $0.1,0.2,0.5,1,2,5$, and $10 \mu \mathrm{g} / \mathrm{L} \mathrm{Ag}$ standards were used for the calibration graphic and CRM-TMDW (trace metals in drinking water standard) certified reference material was used for verification (Protocol no. 186; Nordic Committee of Food Analysis, Julshamn et al., 2007).

In the first data set, TAC was used as the dependent variable $(y)$ in the statistical analyses. Independent factors ( $\mathrm{x}$ ) were time, temperature, and accelerating voltage. In the second data set, yeasts and molds, coliforms, E. coli, and Staph. aureus counts were used as the dependent variables (y). Sample (initial load, control, AgNP100, and pasteurized milk) was the independent variable in the second data set. The counts were transformed by taking their log to eliminate the skewness and kurtosis usually associated with numbers in such studies. All statistics were carried out using SAS V8.2 software (SAS Institute, 1999).

Table 3. Temperature $\times$ voltage interactions for total aerobic count $(\mathrm{LSM} \pm \mathrm{SE} ; \log \mathrm{cfu} / \mathrm{mL})$ in control and AgNP100-treated milk samples ${ }^{1}$

\begin{tabular}{lccc}
\hline Sample $^{1}$ & $10^{\circ} \mathrm{C}$ & $18^{\circ} \mathrm{C}$ & $22^{\circ} \mathrm{C}$ \\
\hline Control & $7.02^{\mathrm{A}, \mathrm{c}} \pm 0.01$ & $7.10^{\mathrm{A}, \mathrm{b}} \pm 0.01$ & $7.14^{\mathrm{A}, \mathrm{a}} \pm 0.01$ \\
AgNP100 & $6.74^{\mathrm{B}, \mathrm{b}} \pm 0.01$ & $7.05^{\mathrm{B}, \mathrm{a}} \pm 0.01$ & $6.86^{\mathrm{B}, \mathrm{a}} \pm 0.01$ \\
\hline
\end{tabular}

${ }^{\mathrm{a}-\mathrm{c}}$ Values within a row with different superscripts differ $(P<0.05)$.

${ }^{\mathrm{A}, \mathrm{B}}$ Values within a column with different superscripts differ $(P<0.05)$.

${ }^{1}$ Control $=$ milk sample with no silver nanoparticle $(\mathrm{AgNP})$ wire; $\mathrm{AgNP} 100=$ milk samples incubated with AgNP wires coated using $100 \mathrm{~V}$. 
Table 4. Total aerobic count (TAC; LSM \pm SE) for different times

\begin{tabular}{lc}
\hline Time & $\begin{array}{c}\text { TAC } \\
(\log \mathrm{cfu} / \mathrm{mL})\end{array}$ \\
\hline $1 \mathrm{~s}$ & $6.75^{\mathrm{E}} \pm 0.008$ \\
$30 \mathrm{~s}$ & $6.95^{\mathrm{C}} \pm 0.008$ \\
$10 \mathrm{~min}$ & $7.04^{\mathrm{B}} \pm 0.008$ \\
$1 \mathrm{~h}$ & $6.91^{\mathrm{D}} \pm 0.008$ \\
$10 \mathrm{~h}$ & $7.32^{\mathrm{A}} \pm 0.008$ \\
\hline${ }^{\mathrm{A}-\mathrm{E}}$ Values with different superscripts differ $(P<0.05)$.
\end{tabular}

\section{RESULTS AND DISCUSSION}

The first data set included the effects of accelerating voltage, time, and temperature. Differences among the effects of accelerating voltages, times, and temperatures were highly significant $(P<0.01)$. All 2 -way interactions among these variables and the 3 -way interaction were highly significant $(P<0.01)$. Overall least squares means of accelerating voltage for TAC are provided in Table 1. Differences among the voltages were large $(P$ $<0.01$ ). The AgNP100 treatment provided the lowest TAC compared with control, followed by AgNP200 and AgNP0. Because the accelerating voltage is an indication of kinetic energy, higher voltages cause the AgNP to stick more to the braided wires. The highest voltage $(200 \mathrm{~V})$ may have caused the particles to stick more to the wires, creating a hard-to-release coating. The 0 $\mathrm{V}$ treatment may have resulted in a coating that was too loose, resulting in an insufficient coating of silver particles on the steel braid surface. However, AgNP100 had the most silver released in the milk, indicating that this was the optimum voltage for the kinetic energy required.

Table 2 shows the overall least squares means for the different temperatures. The microbial load was highest in samples treated at the higher temperatures, with the lowest load being in samples treated at $10^{\circ} \mathrm{C}$. The difference between the 18 and $22^{\circ} \mathrm{C}$ treatments did not seem to increase the microbial load for overall temperature but the differences were highly significant $(P<0.01)$. Looking at the main effects only, and disregarding the interaction effects, can be misleading. For example,

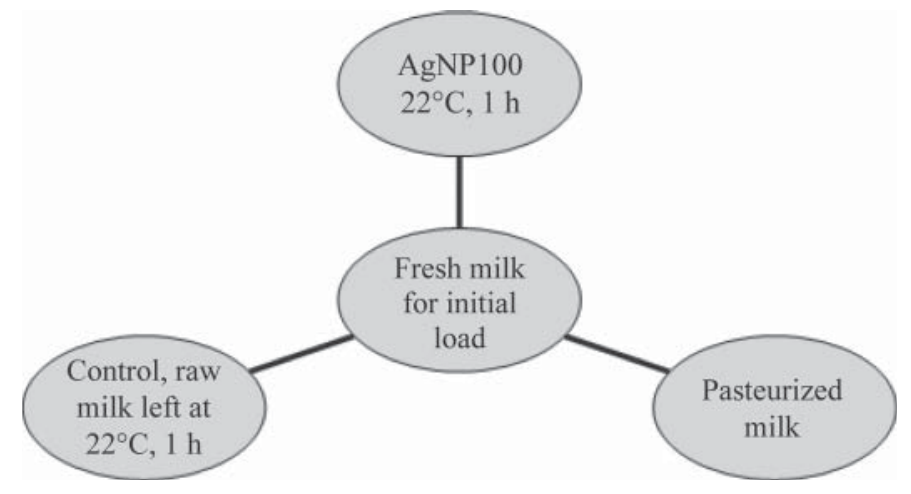

Figure 3. The main trial involving initial load, control, and treatment (milk samples incubated with silver nanoparticle wires coated using $100 \mathrm{~V})$.

the temperature and accelerating voltage interaction (Table 3) will provide more detailed information and better resolution, compared with the temperature main effect only. The AgNP100 treatment was more effective in milk samples incubated at $22^{\circ} \mathrm{C}$ compared with those incubated at $18^{\circ} \mathrm{C}$ treatment in lowering the microbial load. Although the microbial load in $\mathrm{AgNP} 100$ at $10^{\circ} \mathrm{C}$ was lower in absolute value, the increase in microbial load was not as high at this temperature, as seen by TAC in the control sample. However, all differences between the control and AgNP100 were significant $(P<$ $0.05)$, indicating that the particles were highly effective at all temperatures tested (Table 3).

Overall TAC least squares means are provided in Table 4 for the different times investigated; all differences were significant $(P<0.01)$. The highest count was observed with a treatment time of $10 \mathrm{~h}$, and the lowest count was observed for the 1-s waiting time. Although these are overall values and the main effects may include effects of the other factors, the interaction of time by treatment (Table 5) provided a clearer picture. Differences between the control and AgNP100 samples for $1 \mathrm{~h}$ were very large $(P<0.001)$, whereas the differences between the control and AgNP100 for $10 \mathrm{~h}$ were not significant $(P=0.52)$. This indicated that effectiveness of the AgNP100 decreased as the duration increased,

Table 5. Time $\times$ voltage interactions for total aerobic count (LSM \pm SE; log cfu/mL) in control and treated milk samples

\begin{tabular}{|c|c|c|c|c|c|}
\hline Sample $^{1}$ & $1 \mathrm{~s}$ & $30 \mathrm{~s}$ & $10 \mathrm{~min}$ & $1 \mathrm{~h}$ & $10 \mathrm{~h}$ \\
\hline $\begin{array}{l}\text { Control } \\
\text { AgNP100 }\end{array}$ & $\begin{array}{l}6.94^{\mathrm{A}, \mathrm{c}} \pm 0.02 \\
6.50^{\mathrm{B}, \mathrm{e}} \pm 0.02\end{array}$ & $\begin{array}{l}7.03^{\mathrm{A}, \mathrm{b}} \pm 0.02 \\
6.87^{\mathrm{B}, \mathrm{c}} \pm 0.02\end{array}$ & $\begin{array}{l}7.05^{\mathrm{A}, \mathrm{b}} \pm 0.02 \\
6.99^{\mathrm{B}, \mathrm{b}} \pm 0.02\end{array}$ & $\begin{array}{l}7.07^{\mathrm{A}, \mathrm{b}} \pm 0.02 \\
6.76^{\mathrm{B}, \mathrm{d}} \pm 0.02\end{array}$ & $\begin{array}{l}7.33^{\mathrm{A}, \mathrm{a}} \pm 0.02 \\
7.31^{\mathrm{A}, \mathrm{a}} \pm 0.02\end{array}$ \\
\hline & & & $\frac{0.99 \quad \pm 0.02}{20}$ & & \\
\hline
\end{tabular}




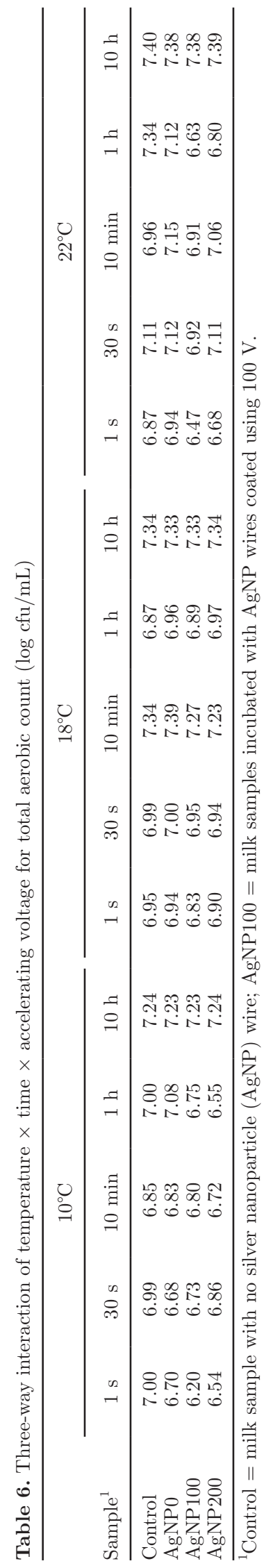

suggesting that the particles stop inhibiting or reduce their inhibition activities after a certain period. This finding might be useful in that milk treated in this way could later be used for dairy products such as cheese and yogurt, which require microorganism activity.

The differences between the control and treatment were most clear in the $1 \mathrm{~h}$ treatment and the differences were significant. All other differences were also significant between the control and AgNP100; however, the absolute differences were larger in the $1 \mathrm{~h}$ treatment. Table 5 illustrates that microbial load increased steadily as time increased.

Three-way interactions of temperature by time by accelerating voltage are provided in Table 6, showing details of increases and decreases in the first experiment. The trends were as expected, with some small deviations from the norm.

Microorganism by treatment interaction was not significant $(P=0.92)$, which indicated that differences among the treatments and control did not differ for different microorganisms. The treatment was effective for all microorganisms. The overall count differences among the microorganisms were highly significant $(P$ $<0.001)$, which was expected. The differences for the treatment factor were also highly significant $(P<0.01)$, indicating that bacterial counts were significantly different among the initial load, treatment, pasteurized, and control samples.

Least squares means of the different counts of microorganisms used in the second experiment are provided in Table 7. Coliform bacteria are a good indication of contamination and can be used as indicator bacteria (Gleeson and Gray, 1997). Coliform counts were decreased significantly $(P<0.05)$ by AgNP100 compared with the control, and all differences were significant $(P<0.05)$ except for those between the treatment and initial load $(P>0.05)$. This indicates that the nanoparticles inhibited coliform bacteria growth. This effect shows the potential of using AgNP100 particles to reduce viable coliform counts following postpasteurization contamination. Sengul et al. (2011) used photosonication treatment for inactivation of total and coliform bacteria in milk and reported results similar to those achieved using a thermal process. Those authors were investigating alternative methods to thermal processing, whereas the method using the nanoparticlecoated braids used here is a complementary method, not an alternative method.

Escherichia coli counts showed a trend similar to total coliform counts, although the counts were generally lower. The lowest counts were found in pasteurized samples and AgNP100, and the highest count was in the control sample. The AgNP100 sample showed an E. coli count lower than that of the initial load and control 
Table 7. Least squares means of specific microorganism counts (log cfu/mL $\pm \mathrm{SE}$ )

\begin{tabular}{lrccc}
\hline & \multicolumn{4}{c}{ Sample $^{1}$} \\
\cline { 2 - 5 } Microorganism & \multicolumn{1}{c}{ Initial load } & Pasteurized & AgNP100 & Control \\
\hline Coliform & $1.75^{\mathrm{b}} \pm 0.16$ & $0.70^{\mathrm{c}} \pm 0.28$ & $1.72^{\mathrm{b}} \pm 0.13$ & $2.31^{\mathrm{a}} \pm 0.16$ \\
Escherichia coli & $1.35^{\mathrm{ab}} \pm 0.16$ & $0.00^{\mathrm{c}} \pm 0.28$ & $1.02^{\mathrm{b}} \pm 0.13$ & $1.56^{\mathrm{a}} \pm 0.16$ \\
Yeasts and molds & $1.92^{\mathrm{a}} \pm 0.16$ & $1.18^{\mathrm{b}} \pm 0.28$ & $1.91^{\mathrm{a}} \pm 0.13$ & $2.14^{\mathrm{a}} \pm 0.16$ \\
Staphylococcus aureus & $5.90^{\mathrm{ab}} \pm 0.16$ & $4.74^{\mathrm{c}} \pm 0.28$ & $5.69^{\mathrm{b}} \pm 0.13$ & $6.20^{\mathrm{a}} \pm 0.16$ \\
\hline
\end{tabular}

${ }^{a-c}$ Values within a row with different superscripts differ $(P<0.05)$.

${ }^{1}$ Initial load $=$ count of milk samples microbial load at the start of the experiment; Pasteurized $=$ microbial load after pasteurization; AgNP100 = milk samples kept with silver nanoparticle (AgNP) wires coated using $100 \mathrm{~V}$; Control = milk sample with no AgNP wire.

samples, and the difference between the AgNP samples and all others were significant $(P<0.05)$. Counts of $E$. coli are an indication of fecal contamination (Feng et al., 2002), and reducing the $E$. coli load is very important because increased $E$. coli counts may cause food poisoning and product recalls.

Yeast and mold counts were numerically lower in AgNP100 compared with the initial load but the differences were not significant $(P>0.05)$. The lowest counts were in pasteurized samples, followed by AgNP100, initial load, and control samples. Although the differences were in the same order as the bacteria, the counts were not significantly different $(P>0.05)$ except for pasteurized sample $(P<0.05)$. This indicates that the particles were less effective on yeasts and molds compared with bacteria. A gap exists in the scientific literature related to the mechanisms of antifungal activity by silver nanoparticles (Dallas et al., 2011). Further studies are needed to clarify the mechanism by which silver nanoparticles might act on yeasts and molds in a dairy medium.

Decreased udder health can cause extensive losses in milk yield, milk quality, and milk persistency in dairy animals (Pala and Koyuncu, 2007; Koyuncu and Pala, 2008). Staphylococcus aureus is one of the important causal factors of mastitis in dairy animals because of the large polysaccharide capsule protecting it from detection by the immune system (Cenci-Goga et al., 2003). Counts of Staph. aureus in AgNP100 were lower than those in control samples and the differences were significant $(P<0.05)$. Counts of Staph. aureus in
AgNP100 were lower than the initial load as well, but the differences were not significant $(P>0.05)$. This result is consistent with the other bacteria tested and indicates that AgNP100 treatment of the milk samples inhibited bacterial growth and decreased the original count compared with the control $(P<0.05)$. Similarly, Panacek et al. (2006) and Brandt et al. (2011) reported that methicillin-resistant Staph. aureus was killed by silver nanoparticles. Although rare instances of silver-resistant bacteria may exist due to overuse of silver in heavy industrial applications, nanotechnology facilitates a rapid response to resistant bacteria. Su et al. (2011) developed a nanohybrid having strong antibacterial activity against silver-resistant E. coli and methicillin-resistant Staph. aureus.

All of the treatment wires had higher silver nanoparticles leaching into the milk compared with the control, as proved by their significant differences compared with control (Table 8). The current reference dose for oral silver exposure is $5 \mu \mathrm{g} / \mathrm{kg}$ per day (Hill, 2009). This means that a $70-\mathrm{kg}$ human may consume $5 \times 70=350$ $\mu \mathrm{g}$ of silver daily. Values provided in Table 8 were all $<1 \mu \mathrm{g}$. The greatest amount was observed for the most effective treatment (AgNP100) and was $0.61 \mu \mathrm{g} / 100$ $\mathrm{mL}$ or $6.1 \mu \mathrm{g} / \mathrm{L}$. A person drinking a gallon of milk per day might consume $6.1 \times 3.78 \approx 23 \mu \mathrm{g}$, which is well below the safety limit of $5 \mu \mathrm{g} / \mathrm{kg}$ per day.

Studies run in laboratory animals such as mice tend to focus on much higher volumes of nanoparticles, such as milligrams per kilograms of BW. A recent study by Park et al. (2010) investigated toxicity of silver

Table 8. Inductively coupled plasma mass spectroscopy of silver $(\mu \mathrm{g} / 100 \mathrm{~mL}$ of milk; LSM $\pm \mathrm{SE})$ in milk samples ${ }^{1}$ stored at $22^{\circ} \mathrm{C}$ for $1 \mathrm{~h}$

\begin{tabular}{lccc}
\hline Control & AgNP0 & AgNP100 & AgNP200 \\
\hline $0.29^{\mathrm{c}} \pm 0.04$ & $0.48^{\mathrm{b}} \pm 0.04$ & $0.61^{\mathrm{a}} \pm 0.04$ & $0.41^{\mathrm{b}} \pm 0.04$ \\
${ }^{\mathrm{a}-\mathrm{c}}$ Values with different superscripts differ $(P<0.05)$. \\
${ }^{1}$ Control = milk sample with no silver nanoparticle $($ AgNP $)$ & wire; AgNP0, AgNP100, and AgNP200 = milk \\
samples incubated with AgNP wires coated using 0, 100, and 200 V.
\end{tabular}


nanoparticles of different particle sizes by treating mice with AgNP for $14 \mathrm{~d}$ by oral administration. Those researchers administered AgNP in doses of 250, 500, and $1,000 \mu \mathrm{g} / \mathrm{kg}$ and reported that adverse effects on liver and kidney were observed in the highest dose group only. Another study by Park et al. (2011) using particles $7.9 \mathrm{~nm}$ in diameter confirmed that most AgNP were found in feces after oral administration. The same authors reported that the blood concentration for the particles was very low, suggesting that absorption through the gastrointestinal tract was poor. However, in vitro studies report toxic effects of AgNP (Tang and Xi, 2008; AshaRani et al., 2009; Kawata et al., 2009). This warrants further research into the long-term safety of nanoparticle treatment specific to the dairy industry and the consumption of fluid food containing silver nanoparticles.

Small-diameter AgNP could be applied to the inner walls of milking equipment such as milk cans, tanks, and pipes, and silver nanoparticle-coated braids could be used in the dairy industry. Application of this technology in dairy has benefits to the industry, such as improved bacterial control. The technique used here can be used in conjunction with current techniques.

\section{CONCLUSIONS}

Silver nanoparticles controlled bacterial growth whether duration of treatment was $1 \mathrm{~s}, 1 \mathrm{~h}$, or $10 \mathrm{~h}$. The particles started losing their inhibitive properties after $10 \mathrm{~h}$, which indicates that the particle-treated fluid milk could be used to produce cultured dairy products such as yogurt. Treatment with the AgNP-coated wires was most effective at $22^{\circ} \mathrm{C}$. The AgNP100 treatment was most effective at controlling microbial load. For all microorganisms (TAC, coliforms, yeasts and molds, $E$. coli, and Staph. aureus), the highest counts were found in control samples, followed by initial load, AgNP100, and pasteurized samples, indicating that AgNP inhibited microorganism growth and is useful in complementing the cooling chain and thermal processes. The results warrant further research to address sensory properties of fluid milk as well as properties of cheese and yogurt made with the particle-treated milk, and the long-term safety of these products.

\section{ACKNOWLEDGMENTS}

This project was partially supported by Scientific Research Commission of Canakkale 18 Mart University (Canakkale, Turkey). We also thank Alistair Kean (Mantis Deposition, Thame, UK) for his help.

\section{REFERENCES}

AshaRani, P. V., L. K. Mun, G. M. P. Hande, and S. Valiyaveettil. 2009. Cytotoxicity and genotoxicity of silver nanoparticles in human cells. ACS Nano 3:279-290.

Baker, C., A. Pradhan, L. Pakstis, D. J. Pochan, and S. I. Shah. 2005. Synthesis and antibacterial properties of silver nanoparticles. J. Nanosci. Nanotechnol. 5:244-249.

Bertrand, S., R. Houel, E. Vermes, C. Soustelle, M. L. Hillion, and L. Loisance. 2000. Preliminary experience with Silzone-coated St. Jude medical valves in acute infective endocarditis. J. Heart Valve Dis. 9:131-134.

Brandt, O., M. Mildner, A. E. Egger, M. Groessl, U. Rix, M. Posch, B. K. Keppler, C. Strupp, B. Mueller, and G. Stingl. 2011. Nanoscalic silver possesses broad-spectrum antimicrobial activities and exhibits fewer toxicological side effects than silver sulfadiazine. Nanomedicine doi:10.1016/j.nano.2011.07.005.

Brutel de la Riviere, A., K. M. Dossche, D. E. Birnbaum, and R. Hacker. 2000. First clinical experience with a mechanical valve with silver coating. J. Heart Valve Dis. 9:123-129.

Cakir, I. 2000. Gida Mikrobiyolojisi ve Uygulamalari. Ankara Universitesi Ziraat Fakultesi Gida Muhendisligi Bolumu. Sim Matbaacilik Ltd. Sti., Ankara, Turkey.

Cenci-Goga, B. T., M. Karama, P. V. Rossitto, R. A. Morgante, and J. S. Cullor. 2003. Enterotoxin production by Staphylococcus aureus isolated from mastitic cows. J. Food Prot. 66:1693-1696.

Dallas, P., V. K. Sharma, and R. Zboril. 2011. Silver polymeric nanocomposites as advanced antimicrobial agents: Classification, synthetic paths, applications, and perspectives. Adv. Colloid Interface Sci. 166:119-135.

Darouiche, R. O. 1999. Anti-infective efficacy of silver-coated medical prostheses. Clin. Infect. Dis. 29:1371-1377.

Dogan, B., and C. Tukel. 2000. Gida Mikrobiyolojisi and Uygulamalari. Ankara Universitesi Ziraat Fakultesi Gida Muhendisligi Bolumu. Sim Matbaacilik Ltd. Sti., Ankara, Turkey.

Feng, P., S. Weagant, and M. Grant. 2002. Enumeration of Escherichia coli and the coliform bacteria. Bacteriological Analytical Manual. 8th ed. FDA/Center for Food Safety and Applied Nutrition, Washington, DC.

Gleeson, C., and N. Gray. 1997. The Coliform Index and Waterborne Disease: Problems of Microbial Drinking Water Assessment. Taylor \& Francis, London, UK.

Graham, C. 2005. The role of silver in wound healing. Br. J. Nurs. 14:S22-S26.

He, D., A. M. Jones, S. Garg, A. N. Pham, and T. D. Waite. 2011. Silver nanoparticles-reactive oxygen species interactions: Application of a charging-discharging model. J. Phys. Chem. C 115:54615468 .

Hill, J. W. 2009. Colloidal Silver Medical Uses, Toxicology and Manufacture. 3rd ed. Clear Springs Press, Rainier, WA.

Hyun, J. S., B. S. Lee, H. Y. Ryu, J. H. Sung, K. H. Chung, and I. J. Yu. 2008. Effects of repeated silver nanoparticles exposure on the histological structure and mucins of nasal respiratory mucosa in rats. Toxicol. Lett. 182:24-28.

Julshamn, K., A. Magge, H. S. Norli, K. H. Grobecker, L. Jorhem, and P. Fecher. 2007. Determination of arsenic, cadmium, mercury, and lead by ICP-MS in foods after pressure digestion: NMKL interlaboratory study. J. AOAC Int. 90:844-856.

Kawata, K., M. Osawa, and S. Okabe. 2009. In vitro toxicity of silver nanoparticles at noncytotoxic doses to HepG2 human hepatoma cells. Environ. Sci. Technol. 43:6046-6051.

Kim, Y. S., J. S. Kim, H. S. Cho, D. S. Rha, J. M. Kim, J. D. Park, B. S. Choi, R. Lim, H. K. Chang, Y. H. Chung, I. H. Kwon, J. Jeong, B. S. Han, and I. J. Yu. 2008. Twenty-eight-day oral toxicity, genotoxicity, and gender-related tissue distribution of silver nanoparticles in Sprague-Dawley rats. Inhal. Toxicol. 20:575-583.

Klueh, U., V. Wagner, S. Kelly, A. Johnson, and J. D. Bryers. 2000. Efficacy of silver-coated fabric to prevent bacterial colonization and subsequent device-based biofilm formation. J. Biomed. Mater. Res. 53:621-631. 
Koyuncu, E., and A. Pala. 2008. Effects of short period frequent milking on milk yield and udder health in Turkish Saanen goats. Anim. Sci. J. 79:111-115.

Lansdown, A. B. G., B. Sampson, P. Laupattarakasem, and A. Vuttivirojana. 1997. Silver aids healing in the sterile skin wound: Experimental studies in the laboratory rat. Br. J. Dermatol. 137:728-735.

Li, Y., P. Leung, L. Yao, Q. W. Song, and E. Newton. 2006. Antimicrobial effect of surgical masks coated with nanoparticles. J. Hosp. Infect. 62:58-63.

Pala, A., and E. Koyuncu. 2007. Effects of short period frequent milking on persistency of milk yield and SCS in Turkish Saanen goats. Anim. Sci. J. 78:400-406.

Panacek, A., L. Kvitek, R. Prucek, M. Kolar, R. Vecerova, N. Pizurova, V. K. Sharma, T. Nevecna, and R. Zboril. 2006. Silver colloid nanoparticles: Synthesis, characterization, and their antibacterial activity. J. Phys. Chem. B 110:16248-16253.

Park, E. J., E. Bae, J. Yi, Y. Kim, K. Choi, S. H. Lee, J. Yoon, B. C. Lee, and K. Park. 2010. Repeated-dose toxicity and inflammatory responses in mice by oral administration of silver nanoparticles. Environ. Toxicol. Pharmacol. 30:162-168,

Park, K., E. J. Park, I. K. Chun, K. Choi, S. H. Lee, J. Yoon, and B. C. Lee. 2011. Bioavailability and toxicokinetics of citrate-coated silver nanoparticles in rats. Arch. Pharm. Res. 34:153-158.

Pedahzur, R., H. I. Shuval, and S. Ulitzur. 1997. Silver and hydrogen peroxide as potential drinking water disinfectants: Their bactericidal effects and possible modes of action. Water Sci. Technol. 35:87-93
Pérez-Tijerina, E., M. Gracia Pinilla, S. Mejía-Rosales, U. Ortiz-Méndez, A. Torres, and M. José-Yacamán. 2008. Highly size-controlled synthesis of $\mathrm{Au} / \mathrm{Pd}$ nanoparticles by inert-gas condensation. Faraday Discuss. 138:353-362.

SAS Institute. 1999. SAS OnlineDoc. Version 8. SAS Institute Inc., Cary, NC

Sengul, M., T. Erkaya, M. Baslar, and M. F. Ertugay. 2011. Effect of photosonication treatment on inactivation of total and coliform bacteria in milk. Food Contr. 22:1803-1806.

Speroni, M., G. Pirlo, and S. Lolli. 2006. Effect of automatic milking systems on milk yield in a hot environment. J. Dairy Sci. 89:4687-4693.

Su, H. L., S. H. Lin, J. C. Wei, I. C. Pao, S. H. Chiao, C. C. Huang, S Z. Lin, and J. J. Lin. 2011. Novel nanohybrids of silver particles on clay platelets for inhibiting silver-resistant bacteria. PLoS ONE $6: \mathrm{e} 21125$.

Tang, J., and T. Xi. 2008. Status of biological evaluation on silver nanoparticles. Sheng Wu Yi Xue Gong Cheng Xue Za Zhi 25:958961.

Tukel, C. and B. Dogan. 2000. Gida Mikrobiyolojisi and Uygulamalari. Ankara Univeristesi Ziraat Fakultesi Gida Muhendisligi Bolumu. Sim Matbaacilik Ltd. Sti., Ankara, Turkey.

Unluturk, A., and F. Turantas. 2002. Gidalarin Mikrobiyolojik Analizi. Meta Matbaacilik, Bornova-Izmir, Turkey.

Voccia, S., M. Ignatova, R. Jerome, and C. Jerome. 2006. Design of antibacterial surfaces by a combination of electrochemistry and controlled radical polymerization. Langmuir 22:8607-8613. 